\title{
Uma boate barata, uma mesa solitária, um quarto fechado e um vestido novo
}

Para iniciar a leitura deste número, convidamos o leitor a calçar um par de sapatinhos vermelhos.

Eles se encontram no primeiro artigo da revista, envoltos em um papel de seda azul clarinho, na terceira gaveta de um armário. São excessivamente altos e podem causar severos ferimentos nos pés, não pelo salto, mas porque, quando os colocamos, nos transformamos em outras pessoas. Saímos do abandono, da falta de amor, da passividade da nossa vida cotidiana, para experimentar os prazeres e sensações extremas a partir da literatura.

Sem esses sapatos nos pés, o leitor não se atreveria a entrar nesta revista-on-lineboate-barata e dançar loucamente com todos os artigos que o olharem fixamente, sejam eles altos, baixos, negros ou louros.

Edinael Sanches Rocha, em "O sino do amor e o badalar do recalque: notas sobre Dão-lalalão, de Guimarães Rosa", ensina os passos da nossa insólita dança crítica: "o ir e vir de um pólo a outro, semelhante ao badalar de um sino, apontando para a dinâmica ininterrupta do movimento entre um elemento e seu contrário". Neste segundo artigo, o ir e vir leva-nos incessantemente da literatura à psicanálise, de Dão-Lalalão a LãoDalalão, da dona de casa à prostituta, do passado ao presente, do imperfeito ao mais que perfeito, do mingau branco ao barro preto, do recalque ao desejo.

No texto seguinte, "Proust: la recherche du sens", de Larissa Drigo Agostinho, encontramos a garantia de que, pelo menos, não estamos perdendo o tempo: afinal, "a única vida realmente vivida é a literatura", como afirma Proust em 0 tempo redescoberto. Mas para chegar a essa vida realmente vivida, para chegar à essência das coisas, dos lugares, das pessoas, é preciso também seguir um movimento de ir e vir. Assim, partimos da sensação "real" e nos deslocamos em direção à sua destruição, seguimos o caminho da experiência e a transformamos em pensamento, para finalmente abandonar a morte (expressa na lembrança), e abraçar a vida realmente vivida pela leitura e escritura de um romance.

Ainda no mesmo passo, conduzidos por Proust, encontramos agora Cervantes e o seu Quixote no artigo "O Mosaico Literário Em O Amanuense Belmiro" de Célia Tamura. Essa dança nos conduz num vai-e-vem à leitura, ao mesmo tempo formadora do caráter do personagem Belmiro e também do próprio romance à medida em que Cyro dos Anjos constrói seu mosaico.

Um passo para trás e recuamos no tempo e no espaço em "As Aventuras de Telêmaco: história crítica ereleituras" de Tarsilla Couto de Brito, e somos conduzimos a uma releitura crítica da obra de Fénelon. 0 ritmo agora é uma questão de gênero: manual de príncipes, conto filosófico, romance?

Já em "O dissecador de passarinhos e a idade da razão", de Kleber Pereira dos Santos, nossa dança segue o ir e vir de duas irmãs supostamente inimigas, a recepção e a criação literárias. Do lado da recepção, encontra-se a leitura de $A$ idade da razão, de Jean-Paul Sartre; do lado da criação, a sua reelaboração no romance $O$ ventre, de Carlos Heitor Cony. Aqui, somos introduzidos a um novo passo, já que "quando dois extremos de uma linha que deveria ser reta teimam em se atrair é, talvez, porque não se trata de 
uma linha reta e sim de um círculo". Desta forma, suas reflexões "versam sobre a circularidade da atividade literária, a dinâmica e intensa troca de papéis existente quando um sujeito se depara com uma folha escrita ou em branco".

Mais um passo para trás e nossa companhia agora é a poetisa renascentista Louise Labbé, que nos é apresentada por Annie Finch, na tradução do texto "Paixão em Tradução: Louise Labbé”, de Vitor Alevato do Amaral. A reflexão nos leva às tensões entre significado e forma na poesia, entre a beleza do poema traduzido e a infidelidade ao original, entre os princípios e as incertezas da tradução.

Prosseguindo no mesmo ritmo, continuamos com "O processo de criação do tradutor" de Sérgio Romanelli, que expande a questão da tradução como processo, e nos apresenta mais uma vez uma poetisa, Emily Dickinson, e sua tradutora italiana e também poetisa Rina Sara Virigillito. Os passos se dão agora entre a Crítica Genética e Teoria da Tradução, entre uma tradução instintiva e a procura da proximidade ao original, entre a tradução de um texto de outro e a emergência, em um mesmo manuscrito, de um poema seu. $\mathrm{O}$ badalar final se dá aqui entre a figura do tradutor como escritor e, concluímos como Finch, "que o tradutor e o traduzido servem à mesma arte; que a poesia, no final, tem somente uma língua."

E assim, ao entrar na intimidade escandalosa da criação do poema, consideramos mais apropriado convidar o leitor para a privacidade das quatro paredes do nosso apartamento, ou do nosso grupo Criação e Crítica.

(Mas antes de deixarmos totalmente a boate barata, avistamos ao longe uma mesa solitária, com a resenha do livro "Roland Barthes, o ofício de escrever", de Eric Marty. Juliana Bratfisch conta-nos que, há muito tempo, Barthes e, até hoje, seu discípulo Marty, já seguiam o badalar entre escrita e leitura: para eles, "os textos afirmam e afirmam-se infinitamente, fragmentando-se e tornando-se um entrelugar, uma não-obra que esboça uma possível resposta à impossibilidade da mediação entre pensamento e expressão, refletindo sobre a própria impossibilidade dessa mesma mediação".)

Acenamos para Barthes e Marty, e partimos rumo à intimidade do nosso grupo. Durante o primeiro semestre de 2009, realizamos um curso coletivo sobre "A narrativa francesa do século XX", no qual abordamos velhos autores conhecidos das nossas pesquisas. 0 dossiê deste número contém alguns textos e discussões realizadas no contexto desse curso. Em "Do Universo privado ao espaço aberto, do espaço aberto ao universo fechado" de Samara de Lócio e Silva Geske também fazemos o passo circular entre recepção e criação, mas mergulhamos sem escrúpulos no universo dos manuscritos, rasuras e deslocamentos da escrita de $O$ estrangeiro, de Albert Camus. Passamos do universo privado do manuscrito e seus primeiros leitores ao espaço aberto da crítica literária, para chegar à crítica genética que cria uma tensão entre esses dois espaços.

Mergulhando num movimento contrário, Raphael Luiz Araújo, em "A estética da culpa e a sombra da tradição", atém-se à análise do texto publicado de A Queda. A partir de temas em comum entre essa narrativa e a obra de Baudelaire, especialmente o riso, somos conduzidos à tensão entre maldade e culpabilidade, entre confissão e acusação, entre o monólogo dramático e o romance, entre leitor e interlocutor.

Então, entramos na esfera do pesadelo, nosso próprio pesadelo. 0 mesmo movimento inicial entre irmãs inimigas, transformado novamente em um passo circular da leitura à escrita, aqui nos deixa tontos, nos faz cair. Carolina Messias, em “0 pesadelo 
de um milhão de coisas" nos mostra como o anúncio de uma herança produz, em $A$ Educação sentimental, de Flaubert, a alucinação de um apartamento maravilhosamente mobiliado para receber o grande amor da personagem e, em As coisas, de Perec, somente coisas pelas coisas e mais coisas, sem desejo e sem sujeito.

E como o leitor ainda calça os sapatos vermelhos, ainda que estejamos todos caídos no chão, decidimos continuar com o nosso pesadelo despertado por As coisas, de Georges Perec. Mas neste momento derradeiro expresso pelo artigo de Manlio Speranzini "Aqui tem coisa", a literatura já não nos basta e recorremos às artes plásticas, especificamente à obra Gathering de Daniel Firman (1966). Longe de nos ajudar a recuperar o desejo perdido, a arte de Firman nos arranca o rosto: "Sem rosto ou qualquer indício de esforço, o 'personagem firmaniano' se apresenta de maneira obtusa: por aquilo que acumula. A matéria que o esconde não o explica". A única forma de sair dessa posição dolorosa é então fugir deste território dos artigos, da revista, da crítica.

E assim pedimos ao leitor que tire os sapatinhos vermelhos.

É somente observando de perto as feridas que ficaram em nossos pés que podemos entrar no novo formato proposto por Fernanda Mendes (com diagramação de Priscila Pesce) para pensar a escritura de Proust. Aqui, em vez de articulação entre parágrafos, encontramos costura entre páginas em branco, em vez de acúmulo de citações, uma em cima da outra, vemos os textos serem rasgados, transpassados, fundidos. 0 trabalho não termina com uma frase, mas com uma faixa, que não serve apenas de curativo para os pés, mas de tecido para costurar um novo vestido.

Claudia Amigo Pino

Samara Lócio e Silva Geske

Editoras 